\title{
Effect of Irrigation with Sewage Effluent and Rhizobia Inoculation on Growth of Tropical Tree Legumes in Northeast Brazil
}

\author{
Fabíola G. de Carvalho ${ }^{1}$, Apolino J. N. da Silva ${ }^{2, *}$, Henio N. de S. Melo ${ }^{3}$, Josette L. de S. Melo ${ }^{3}$ \\ ${ }^{1}$ Diretoria Acadêmica de Recursos Naturais, Instituto Federal de Educação, Ciência e Tecnologia do Rio Grande do Norte, \\ Av. Senador Salgado Filho, 1559, Tirol, CEP 59015-000, Natal, RN, Brasil \\ ${ }^{2}$ Unidade Acadêmica Especializada em Ciências Agrárias Escola Agrícola de Jundiaí, Universidade Federal \\ do Rio Grande do Norte, Caixa Postal 07, CEP 59280-000, Macaíba, RN, Brasil \\ ${ }^{3}$ Departamento de Engenharia Química, Universidade Federal do Rio Grande do Norte \\ Campus Universitário, CEP 59072-970, Natal, RN, Brasil
}

\begin{abstract}
The use of domestic sewage in the agriculture is an alternative for reduction of the pollution of rivers, preservation of resources hydrics and availability of water and nutritious for plants. An experiment was conducted to investigate the effects of irrigation with sewage effluent and rhizobia inoculation on growth parameters and macro and micronutrients contents in shoots of leguminous trees grown in an Alisol in northeastern Brazil. Irrigation with sewage effluent and rhizobium inoculation affected significantly the growth parameters and nodulation of L. leucocephala and M. caesalpiniaefolia. Statistically higher values of shoot dry matter and plant height were observed in leguminous trees irrigated with sewage effluent, compared to treatment with water irrigation.Sewage effluent irrigation treatment also increased significantly the contents of N, P, K, Ca, Mg, Fe, Zn and Mn in shoots of woody legumes studied after harvest. Inoculation with Rhizobium promoted significant increases in growth parameters and macro and micronutrients contents, only when associated with application of sewage effluent.
\end{abstract}

Keywords LeucaenaLeucocephala, Mimosa Caesalpiniaefolia, Shoot Dry Matter, Macronutrients, Micronutrients, Tropical Soils

\section{Introduction}

The need to preserve the resources hydrics and the liberation of waters of better quality for nobler uses, as the domestic supply, impelled the use of several types of wastewater in agriculture[31].Sanitary sewage presents great threat to the environment when inadequately thrown in water bodies. However, they can be treated and used in the agriculture without causing environmental risks or transmission of diseases[17].

The treated wastewater irrigation is expected to gain increased importance, requiring careful considerations involving the adequate balance between nutritional inputs via irrigation and optimal plant productivity requirements[24]. Aside from economical benefits acquired for diverse climatic and soil conditions, crop irrigation with treated sewage effluents constitutes an ecologically sound method for the disposal of effluents into the environment[39]. The use of

* Correspondingauthor:

ajndas@ufrnet.br (Apolino J. N. da Silva)

Published online at http://journal.sapub.org/ijaf

Copyright (C) 2012 Scientific \& Academic Publishing. All Rights Reserved sewage effluent irrigation in irrigated agriculture has been studied in various cultures[2,23,26,30]. Forage plants has been chosen for irrigation with sewage effluent because of the long growing season associated with high nutrient uptake capacity and the ability to prevent erosion processes[16]. Some studies show increases in growth parameters such as dry matter and plant height: alfalfa[19]; 'Tifton 85 ' hybrid bermudagrass[16]; bermudagrass[19] and forage corn[28]. For maize increases in dry matter[4] and silage yield[29] were observed after sewage effluents irrigation.

Several leguminous trees are used as forages, and studies of the literature report its ability to N2-fixation by symbiosis with Rhizobium[10,11,18]. The tropical legume leucena (Leucaenaleucocephala) and sabiá (Mimosa caesalpiniaefolia) are multipurpose tree and are used for animal forage, wood production, fuel production, reforestation, stakes and coal, being adapted to semi-arid tropical regions of the Brazil[22,36,37]. However, there is a general lack of information regarding the effects of irrigation with sewage effluent on the growth parameters and nutrient uptake of woody legumes.

The aim of this study was to evaluate the effect of the application of sewage effluent and rhizobia inoculation on 
growth parameters and nutrient uptake of leguminous trees.

\section{Materials and Methods}

\subsection{Plant and Soil Characteristics}

The study was carried out in the region of the coastal tablelands, in the UFRN Experimental Station of Treatment of Sewages, in Natal city, Rio Grande do Norte State, Brazil. The soil used were a Yellow Red Argisoil in the Brazilian System of Soil Classification[13], corresponding to an Alisol in FAO legend[15], collected in area of degraded pasture, located in the Rockfeller farm, municipality of São Gonçalo do Amarante, Rio Grande do Norte State, Brazil. The soil mineralogy is characterized by minerals of variable charge, with $<7 \%$ iron oxides and presence of kaolinite in the clay fraction. The chemical and physical characteristics of the studied soil are listed in the Table 1. The mean annual temperature of the studied area is $26^{\circ} \mathrm{C}$ and the average annual rainfall is $1500 \mathrm{~mm}[21]$.

Table 1. Some physical and chemical characteristics of the soil used in the experiment

\begin{tabular}{|c|c|}
\hline Characteristics & Mean* \\
\hline $\mathrm{pH}$ & 5.6 \\
\hline $\mathrm{Al}^{3+}(\mathrm{cmolc} . k g-1)$ & 0.11 \\
\hline $\mathrm{H}^{+}$(cmolc.kg-1) & 2.39 \\
\hline $\mathrm{Ca}^{2+}($ cmolc.kg-1) & 0.20 \\
\hline $\mathrm{Mg}^{2+}($ cmolc.kg-1) & 0.14 \\
\hline $\mathrm{K}^{+}($cmolc.kg-1) & 0.32 \\
\hline $\mathrm{Na}^{+}($cmolc.kg-1 $)$ & 0.18 \\
\hline $\mathrm{P}(\mathrm{mg} \cdot \mathrm{dm}-3)$ & 3.00 \\
\hline Sand $(\mathrm{g} \mathrm{kg}-1)$ & 859 \\
\hline Clay $(\mathrm{g} \mathrm{kg}-1)$ & 20 \\
\hline Silt $(\mathrm{g} \mathrm{kg}-1)$ & 121 \\
\hline
\end{tabular}

* Data are means of 3 replications.

The tropical tree legume leucena (Leucaenaleucocephala) and sabiá (Mimosa caesalpiniaefolia) were used as plants tests, which have great potential for recuperation of degraded areas. The seeds of L. leucocephala were furnished by the Centre of Agricultural Researches of the Semiarid Tropics (EMBRAPA) and seeds of M. caesalpiniaefolia by the Institute of Forest Researches.

\subsection{Plant Inoculation and Experimental Conditions}

The legumes $L$. leucocephalaand M. caesalpiniaefolia were planted in plastic pots $(8 \mathrm{~L})$, each filled with $10 \mathrm{~kg}$ of soil (0-0.2 $\mathrm{m}$ layer), being made, 40 days before the planting, the application of lime and fertilization with phosphorus, following recommendation for tree legumes for the State of Pernambuco, Brazil[20].

Treatments consisted of legumes irrigated with water and inoculated with rhizobium; legumes irrigated with domestic sewage effluent and inoculated with rhizobium; legumes irrigated with water and without inoculation; and legumes irrigated with domestic sewage effluent and without inoculation.
The rhizobium strains used in the research for inoculation were furnished by the Company of Brazilian Agricultural Research (EmbrapaAgrobiologia).Seeds were surface- sterilised with $95 \%$ ethanol for $10 \mathrm{~min}$, washed six times with sterilized water and soaked overnight to imbibe water. Seedlings of L. leucocephala were inoculated with Bradyrhizobium strains (BR 825 and BR 827) and M. caesalpiniaefolia with Bradyrhizobium strains (BR 3407 and BR 3446). After the incubation period, soil moisture was kept at $80 \%$ of field capacity throughout the experiment, in the areas irrigated with water and with the domestic sewage effluent, through a drip irrigation system, and using lateral plastic drains in the pots.

The pots were distributed in two areas with dimensions of $3,5 \mathrm{~m} \times 3,5 \mathrm{~m}$, arranged in a completely randomized factorial design with 3 replications. In the first area the pots were irrigated with water and in the second area the pots were irrigated with domestic sewage effluent, originating from UFRN Station of Anaerobic Treatment of Sewages. The amount and frequency of irrigation were the same for every treatment and both crops. The amount of irrigation was 3 $\mathrm{mm} /$ day from planting to harvest the plants. Table 2 shows the chemical and microbiological characteristics of sewage effluent used in the experiment[27].

Table 2. Chemical composition of sewage effluent used in the experiment

\begin{tabular}{|c|c|}
\hline Characteristics & Mean $^{* *}$ \\
\hline $\mathrm{pH}$ & 7.00 \\
\hline $\mathrm{N}-\mathrm{NH}_{4}{ }^{+}\left(\mathrm{mgL}^{-1}\right)$ & 39.43 \\
\hline $\mathrm{P}\left(\mathrm{mgL}^{-1}\right)$ & 2.13 \\
\hline $\mathrm{K}^{+}\left(\mathrm{mgL}^{-1}\right)$ & 16.70 \\
\hline $\mathrm{Ca}^{2+}\left(\mathrm{mgL}^{-1}\right)$ & 7.10 \\
\hline $\mathrm{Mg}^{2+}\left(\mathrm{mgL}^{-1}\right)$ & 5.99 \\
\hline $\mathrm{S}\left(\mathrm{mgL}^{-1}\right)$ & 6.55 \\
\hline $\mathrm{Na}^{+}\left(\mathrm{mgL}^{-1}\right)$ & 66.25 \\
\hline $\mathrm{Fe}^{2+}\left(\mathrm{mgL}^{-1}\right)$ & 0.37 \\
\hline $\mathrm{Cu}^{2+}\left(\mathrm{mgL}^{-1}\right)$ & 0.06 \\
\hline $\mathrm{Zn}^{2+}\left(\mathrm{mgL}^{-1}\right)$ & 0.03 \\
\hline $\mathrm{Mn}^{2+}\left(\mathrm{mgL}^{-1}\right)$ & 0.02 \\
\hline $\mathrm{CE}^{*}\left(\mathrm{dS} \mathrm{m}^{-1}\right)$ & 0.736 \\
\hline $\mathrm{TS}\left(\mathrm{mgL}^{-1}\right)$ & 380 \\
\hline $\mathrm{COD}\left(\mathrm{mgL}^{-1}\right)$ & 168 \\
\hline Tocal coliforms(MPN 100mL ${ }^{-1}$ ) & $370.10^{-3}$ \\
\hline Fecal coliforms(MPN 100mL-1) & $223.10^{-3}$ \\
\hline
\end{tabular}

${ }^{*} \mathrm{CE}=$ Electrical conductivity; $\mathrm{TS}=$ Total solids; $\mathrm{COD}=$ chemical oxygen demand; MPN = Most Probable Number; ${ }^{* *}$ Data are means of 3 replications.

At 75 days after the planting, the plants were harvested and plant height, shoot dry matter and dry weight of nodules were determined.Plant material was dried at $60^{\circ} \mathrm{C}$ after washing with water followed by two successive rinses in distilled water. Afterward, drying samples were ground to pass 40 mesh screen and stored in plastic vials. The macro and micronutrients were measured in plant material according to Embrapa[12]. Total $\mathrm{N}$ was determined by semi-micro Kjeldhal using an auto-analyser Kjeltec 1030. Sodium and K were determined by flame photometry, $\mathrm{P}$ by colorimetric determination and $\mathrm{Ca}, \mathrm{Mg}, \mathrm{Cu}, \mathrm{Fe}, \mathrm{Mn}$ and $\mathrm{Zn}$ by atomic absorption spectrophotometry. 


\subsection{Statistical Analyses}

The statistical calculations were performed using the ASSISTAT software[34].The results were submitted to analysis of variance (ANOVA) using a completely randomized arrangement and 3 replications. The means were compared by the Tukey's test, considering a significance level of $\mathrm{p}<0.05$ throughout the study. Data accumulated $\mathrm{N}$ and number of nodules were submitted to regression and equations were obtained using Table Curve 2D software, Version 2.0.

\section{Results and Discussion}

\subsection{Plant Growth and Nodulation}

Responses in height, shoot dry matter and nodulation by $L$. leucocephala and M. caesalpiniaefolia following application of sewage effluent and inoculation with rhizobia are presented in tables 3 and 4 respectively.

Table 3. Effect of sewage effluent and of the inoculation with Rhizobium on growth and nodulation of leucena (Leucaenaleucocephala)

\begin{tabular}{|c|c|c|}
\hline Irrigation & With Rhizobium & Without Rhizobium \\
\hline & \multicolumn{2}{|c|}{ Heigth $(\mathrm{cm})$} \\
\hline Water & $20.3 \mathrm{Ab}$ & $21.0 \mathrm{Ab}$ \\
\hline Sewage effluent & $58.3 \mathrm{Aa}$ & $36.3 \mathrm{Ba}$ \\
\hline & \multicolumn{2}{|c|}{ Shoot dry matter $\left(\mathrm{g} \mathrm{plant}^{-1}\right)$} \\
\hline Water & $3.13 \mathrm{Ab}$ & $3.39 \mathrm{Ab}$ \\
\hline Sewage effluent & $11.34 \mathrm{Aa}$ & $9.98 \mathrm{Aa}$ \\
\hline & \multicolumn{2}{|c|}{ Nodule $\left(\mathrm{n}^{\text {o }}\right.$ plant $\left.^{-1}\right)$} \\
\hline Water & $22.0 \mathrm{Ab}$ & $0.0 \mathrm{Ba}$ \\
\hline Sewage effluent & $51.3 \mathrm{Aa}$ & $0.0 \mathrm{Ba}$ \\
\hline
\end{tabular}

Values followed by different letters are significantly different at $\mathrm{P}=0.05$, using the Tukey test.Upper case letter compare data within rows and lower case letters compare data within columns.

Table 4. Effect of sewage effluent and of the inoculation with Rhizobium on growth of sabiá (Mimosa caesalpiniaefolia)

\begin{tabular}{|c|c|c|}
\hline Irrigation & With Rhizobium & Without Rhizobium \\
\hline & \multicolumn{2}{|c|}{ Heigth $(\mathrm{cm})$} \\
\hline Water & $27.3 \mathrm{Ab}$ & $30.5 \mathrm{Ab}$ \\
\hline Sewage effluent & $55.3 \mathrm{Aa}$ & $45.8 \mathrm{Ba}$ \\
\hline & \multicolumn{2}{|c|}{ Shoot dry matter $\left(\mathrm{g} \mathrm{plant}^{-1}\right)$} \\
\hline Water & $6.85 \mathrm{Ab}$ & $5.79 \mathrm{Ab}$ \\
\hline Sewage effluent & $19.29 \mathrm{Aa}$ & $17.26 \mathrm{Aa}$ \\
\hline & \multicolumn{2}{|c|}{ Nodule $\left(\mathrm{n}^{\text {o }}\right.$ plant $\left.^{-1}\right)$} \\
\hline Water & $36.00 \mathrm{Ab}$ & $0.00 \mathrm{Ba}$ \\
\hline Sewage effluent & $98.33 \mathrm{Aa}$ & $0.00 \mathrm{Ba}$ \\
\hline
\end{tabular}

Values followed by different letters are significantly different at $\mathrm{P}=0.05$, using the Tukey test.Upper case letter compare data within rows and lower case letters compare data within columns.

Height of L. leucocephala and M. caesalpiniaefolia were increased significantly $(\mathrm{P}<0.05)$ from 36.3 to $58,3 \mathrm{~cm}$ and 48,5 to $55,3 \mathrm{~cm}$ (Tables 3 and 4 , respectively), due to inoculation with rhizobia, when irrigated with sewage effluent, but was unaffected by inoculation with rhizobia when irrigated with water. This trend was not reflected in shoot dry matter yields of L. leucocephala and M. caesalpiniaefolia, which was not significantly affected by inoculation with rhizobia in the plants irrigated with water and with sewage effluent. Stamford and Silva[38], however, found significant effects of rhizobia inoculation on shoot dry weight of $M$. caesalpiniaefolia, when strains selected to acid soils were used.

Application of sewage effluent increased the heights of $L$. leucocephala and M. caesalpiniaefolia significantly (Tables 3 and 4, respectively), compared to treatment with irrigation water, in both treatments with and without inoculation. These results are consistent with the reported by Bezerra et al. [8], that verified larger cotton height due to the application of domestic sewage effluent.

Irrigation with sewage effluent promoted larger values of shoot dry matter in L. leucocephalaand M. caesalpiniaefolia (Tables 3 and 4, respectively), compared with water irrigation treatment. There was an increase of $262 \%$ in the $L$. leucocephala shoot due to the irrigation with sewage effluent, compared with the plants irrigated with water, when inoculated with rhizobia. In the treatment without inoculation, the increase of shoot dry weight in L. leucocephala irrigated with sewage effluent was of $194 \%$, compared with the plants irrigated with water. The shoot dry matter of M. caesalpiniaefoliahad increases of $182 \%$ and $198 \%$ when irrigated with effluent, compared to irrigation with water, in treatments with and without rhizobia inoculation respectively.

The highest values of height and shoot dry matter of $L$. leucocephalaand M. caesalpiniaefolia when irrigated with sewage effluent, compared to treatments irrigated with water, could be attributed to the presence of appreciable amount of $\mathrm{N}, \mathrm{K}, \mathrm{Ca}, \mathrm{Mg}$ and some other micronutrients essential for plant growth present in sewage effluent (Table 2).

Irrigation with sewage effluent and inoculation with rhizobia affected the nodulation in both plants studied (Tables 3 and 4, respectively). The application of sewage effluent significantly increased the nodulation from 22.0 to 51.3 nodules plant-1 in L. leucocephala (Table 3 ) and from 36.0 to 98.3 nodules plant ${ }^{-1}$ in $M$. caesalpiniaefolia (Table 4), compared with treatments irrigated with water, when inoculated with rhizobia. Al-Fredan[3] also found significant increase in the number of nodules in faba bean, due to application of domestic sewage effluent.

In this study, nodulation of L. leucocephalaand M. caesalpiniaefolia occurred only in treatments inoculated with rhizobium.There was a significant and positive correlation between the nitrogen accumulated in shoot dry matter and number of nodules of $L$. leucocephalaand $M$. caesalpiniaefolia, in the treatments inoculated with rhizobia (Fig. 1). Stamford and Silva[38] observed that inoculation with rhizobium in Alisol resulted in $85 \%$ increase in dry weight of nodules in $M$. caesalpiniaefolia, compared with uninoculated plants. The same authors found no nodulation of $M$. caesalpiniaefolia grown on an Oxisol, in the treatment not inoculated with rhizobium.

The positive and significant correlation between the $\mathrm{N}$ accumulated in the shoot dry matter and nodules number of $L$. leucocephala and M. caesalpiniaefolia (Fig. 1) shows the efficiency of the inoculation with rhizobia, reflecting the fixation of atmospheric nitrogen by plants.Souza et al.[35], 
studying the nodulation of L. leucocephala and M. caesalpiniaefolia not inoculated, despite reporting the nodulation with natives rhizobia, found no significant correlation between number of nodules and nitrogen accumulated.

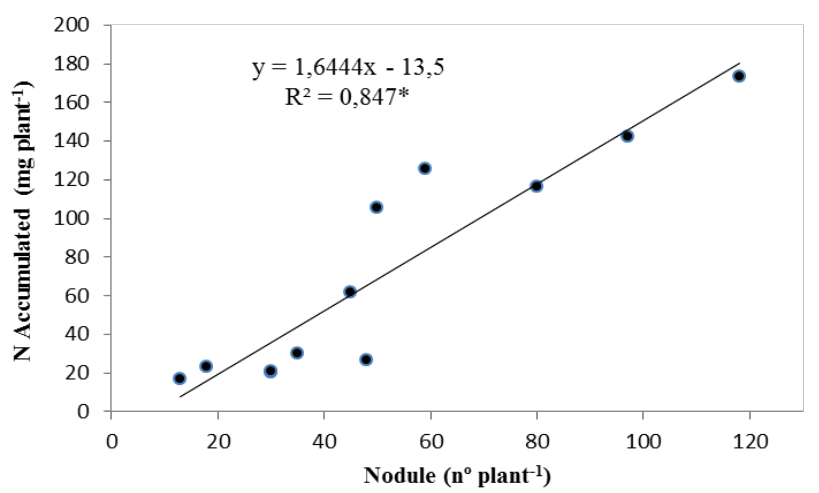

Figure 1. Linear regression of $\mathrm{N}$ accumulated in shoot dry matter and nodule number of L. leucocephala and M. caesalpiniaefolia

The occurrence of nodules in L. leucocephala and $M$. caesalpiniaefolia (Tables 3 and 4, respectively), just in the inoculated plants, shows total absence of native rhizobia in the soil studied, or possibly lack of conditions for nodulation due to the acidic $\mathrm{pH}$ soil.This result shows that there is need for inoculation with rhizobium in L. leucocephala and $M$. caesalpiniaefolia grown in acid soils, to occur the effective nodulation and fixation of atmospheric nitrogen. Chong et al. [9], however, reported that plants excrete different exudates, which can cause changes in $\mathrm{pH}$ near the rhizosphere, allowing nodulation in acidic soils.

Another factor that can affect nodulation of $L$. leucocephala and M. caesalpiniaefolia, when not inoculated, is the low competitiveness of their native rhizobial populations in tropical soils[7]. Souza et al.[35] found low frequencies of the native populations of rhizobia to $L$. leucocephala, with only $22 \%$ of plants nodulated in tropical soils of northeast Brazil, while $86 \%$ of $M$. caesalpiniaefolia plants werenodulated with native strains.

The significantly higher values of nodules in $L$. leucocephala and M. caesalpiniaefolia (Tables 3 and 4, respectively) when irrigated with sewage effluent, show the positive effect of sewage effluent on the symbiosis between rhizobia and plants. Al-Fredan[3] emphasize that the increased nodulation of faba bean irrigated with sewage effluent suggest that the more of the nitrogen in the effluent is used to establish seedlings in the earlier stages, independent of nitrogen fixation, which is reflected in better seedling growth and higher number of nodules.

\subsection{Macronutrients Accumulation}

The accumulation of N, P, Na and $\mathrm{K}$ in shoot dry matter of L. leucocephala was not significantly influenced by rhizobialinoculation $(\mathrm{P}<0.05)$, in the treatments irrigated with waters and with sewage effluent (Tables 5). Leucaenaleucocephala, however, accumulated larger values of $\mathrm{Ca}(51.92$ mg plant-1) and Mg (14.34 mg plant-1) when inoculated with rhizobia and when irrigated with sewage effluent.
The shoot dry matter $\mathrm{N}, \mathrm{Na}$ and $\mathrm{K}$ content were significantly larger when M. caesalpiniaefolia was inoculated with rhizobia, and when plants were irrigated with sewage effluent.However, when irrigated with water, inoculation with rhizobia produced no response in $\mathrm{N}, \mathrm{P}, \mathrm{Ca}, \mathrm{Mg}, \mathrm{Na}$ and $\mathrm{K}$ level in shoots of $M$. caesalpiniaefolia, compared with the treatment without inoculation (Table 6).

Table 5. Effect of sewage effluent and of the inoculation with Rhizobium on macronutrients accumulation in leucena (Leucaenaleucocephala)

\begin{tabular}{|c|c|c|}
\hline \multirow{2}{*}{ Irrigation } & \multicolumn{2}{|c|}{ Inoculation } \\
\hline & With Rhizobium & Without Rhizobium \\
\hline & \multicolumn{2}{|c|}{$\mathrm{N}\left(\mathrm{mg} \mathrm{plant}^{-1}\right)$} \\
\hline Water & $23.34 \mathrm{Ab}$ & $27.81 \mathrm{Ab}$ \\
\hline \multirow[t]{2}{*}{ Sewage effluent } & $97.51 \mathrm{Aa}$ & $85.84 \mathrm{Aa}$ \\
\hline & \multicolumn{2}{|c|}{$\mathrm{P}\left(\mathrm{mg} \mathrm{plant}^{-1}\right)$} \\
\hline Water & $0.52 \mathrm{Ab}$ & $0.54 \mathrm{Ab}$ \\
\hline \multirow[t]{2}{*}{ Sewage effluent } & $2.12 \mathrm{Aa}$ & $1.78 \mathrm{Aa}$ \\
\hline & \multicolumn{2}{|c|}{$\mathrm{Ca}\left(\mathrm{mg} \mathrm{plant}^{-1}\right)$} \\
\hline Water & $12.32 \mathrm{Ab}$ & $13.17 \mathrm{Ab}$ \\
\hline \multirow[t]{2}{*}{ Sewage effluent } & $51.92 \mathrm{Aa}$ & $30.93 \mathrm{Ba}$ \\
\hline & \multicolumn{2}{|c|}{$\operatorname{Mg}\left(\right.$ mg plant $\left.^{-1}\right)$} \\
\hline Water & $5.43 \mathrm{Ab}$ & $4.25 \mathrm{Ab}$ \\
\hline \multirow[t]{2}{*}{ Sewage effluent } & $14.34 \mathrm{Aa}$ & $9.51 \mathrm{Ba}$ \\
\hline & \multicolumn{2}{|c|}{$\mathrm{Na}\left(\mathrm{mg}\right.$ plant $\left.{ }^{-1}\right)$} \\
\hline Water & $1.31 \mathrm{Aa}$ & $1.96 \mathrm{Aa}$ \\
\hline \multirow[t]{2}{*}{ Sewage effluent } & $1.52 \mathrm{Aa}$ & $1.31 \mathrm{Aa}$ \\
\hline & \multicolumn{2}{|c|}{$\mathrm{K}\left(\mathrm{mg} \mathrm{plant}^{-1}\right)$} \\
\hline Water & $39.93 \mathrm{Ab}$ & $44.68 \mathrm{Ab}$ \\
\hline Sewage effluent & $152.27 \mathrm{Aa}$ & $128.86 \mathrm{Aa}$ \\
\hline
\end{tabular}

Values followed by different letters are significantly different at $\mathrm{P}=0.05$, using the Tukey test.Upper case letter compare data within rows and lower case letters compare data within columns.

Table 6. Effect of sewage effluent and of the inoculation with Rhizobium on macronutrients accumulation in sabiá (Mimosa caesalpiniaefolia)

\begin{tabular}{|c|c|c|}
\hline \multirow{3}{*}{ Irrigation } & \multicolumn{2}{|c|}{ Inoculation } \\
\hline & With Rhizobium & Without Rhizobium \\
\hline & \multicolumn{2}{|c|}{$\mathrm{N}\left(\mathrm{mg} \mathrm{plant}^{-1}\right)$} \\
\hline Water & $22.60 \mathrm{Ab}$ & $28.56 \mathrm{Ab}$ \\
\hline \multirow[t]{2}{*}{ Sewage effluent } & $144.04 \mathrm{Aa}$ & $114.11 \mathrm{Ba}$ \\
\hline & \multicolumn{2}{|c|}{$\mathrm{P}\left(\mathrm{mg} \mathrm{plant}^{-1}\right)$} \\
\hline Water & $0.88 \mathrm{Ab}$ & $0.89 \mathrm{Ab}$ \\
\hline \multirow[t]{2}{*}{ Sewage effluent } & $3.70 \mathrm{Aa}$ & $4.09 \mathrm{Aa}$ \\
\hline & \multicolumn{2}{|c|}{$\mathrm{Ca}\left(\mathrm{mg} \mathrm{plant}^{-1}\right)$} \\
\hline Water & $23.07 \mathrm{Ab}$ & $30.00 \mathrm{Ab}$ \\
\hline \multirow[t]{2}{*}{ Sewage effluent } & $83.43 \mathrm{Aa}$ & $87.25 \mathrm{Aa}$ \\
\hline & \multicolumn{2}{|c|}{$\operatorname{Mg}\left(\right.$ mg plant $\left.^{-1}\right)$} \\
\hline Water & $4.46 \mathrm{Ab}$ & $5.43 \mathrm{Ab}$ \\
\hline \multirow[t]{2}{*}{ Sewage effluent } & $23.82 \mathrm{Aa}$ & $21.00 \mathrm{Aa}$ \\
\hline & \multicolumn{2}{|c|}{$\mathrm{Na}\left(\mathrm{mg} \mathrm{plant}^{-1}\right)$} \\
\hline Water & $2.33 \mathrm{Aa}$ & $2.56 \mathrm{Aa}$ \\
\hline \multirow[t]{2}{*}{ Sewage effluent } & $2.48 \mathrm{Aa}$ & $2.11 \mathrm{Ba}$ \\
\hline & \multicolumn{2}{|c|}{$\mathrm{K}\left(\mathrm{mg} \mathrm{plant}^{-1}\right)$} \\
\hline Water & $69.54 \mathrm{Ab}$ & $69.86 \mathrm{Ab}$ \\
\hline Sewage effluent & $253.37 \mathrm{Aa}$ & $221.86 \mathrm{Ba}$ \\
\hline
\end{tabular}

Values followed by different letters are significantly different at $\mathrm{P}=0.05$, using the Tukey test.Upper case letter compare data within rows and lower case letters compare data within columns.

Data in Tables 5 and 6 showed that application of sewage effluent increased $\mathrm{N}, \mathrm{P}, \mathrm{Ca}, \mathrm{Mg}$ and $\mathrm{K}$ significantly in shoots dry matter of $L$. leucocephala and $M$. caesalpiniaefolia respectively, in relation to the treatments irrigated with water, 
in both treatments with and without rhizobia inoculation.

The highest values of $\mathrm{Ca}$ and $\mathrm{Mg}$ accumulated in shoot dry matter of Leucaenaleucocephala (Tables 5), and the highest values of $\mathrm{N}, \mathrm{Na}$ and $\mathrm{K}$ in M. caesalpiniaefolia (Table 6), when inoculated with rhizobia and when the plants were irrigated with sewage effluent, suggesting that the association among inoculation with rhizobia and the sewage effluent promotes a beneficial effect in the absorption of these macronutrients, compared with the treatment without inoculation and irrigated with water.

The largest accumulated macronutrients values in L. leucocephala and $M$. caesalpiniaefolia irrigated with sewage effluent resulted in larger plant growth (Tables 3 and 4, respectively), as represented by height and shoot dry matter, indicating the positive effect of the effluent of domestic sewage as organic fertilizer.Azevedo and Oliveira[6] verified increased levels of $\mathrm{N}, \mathrm{P}, \mathrm{K}, \mathrm{Ca}, \mathrm{Mg}$ and $\mathrm{S}$ in soil irrigated with sewage effluent, resulting in increased yield of cucumber.Increasing macronutrients concentrations were also observed by Falkiner and Smith[14] in forest soils and in soils cropped with eggplant[5], when irrigated with sewage effluent.

\subsection{Micronutrients Accumulation}

L. leucocephala inoculated with rhizobium presented values significantly higher of $\mathrm{Zn}, \mathrm{Fe}$ and $\mathrm{Mn}$ accumulated in shoot dry matter, in relation to treatment without inoculation, in the soil irrigated with sewage effluent (Table 7), which may have occurred due to increased absorption of these micronutrients, reflecting the greater availability near the rhizosphere.Malavolta[25] emphasizes that when the source of $\mathrm{N}$ for the plant is atmospheric $\mathrm{N} 2$ fixed, there is a greater uptake of cations compared to anions, causing increased excretion of $\mathrm{H}+$ and reduction of rhizosphere $\mathrm{pH}$, which increases the availability of cationic micronutrients and the subsequent absorption by plants.

In relation to the $M$. caesalpiniaefolia, rhizobium inoculation had no significant effect on contents of the micronutrients $\mathrm{Cu}, \mathrm{Zn}$ and $\mathrm{Fe}$ in the shoot. Only the Mn content increased significantly in response to rhizobium inoculation, in soil irrigated with sewage effluent (Table 8). This may be attributed to differences in absorption of nutrients by plant species, due to variation in $\mathrm{pH}$ of the rhizosphere resulting from biological fixation of nitrogen by different species, promoting large variation in the availability of nutrients in the soil[32].

When irrigated with water, the values of $\mathrm{Cu}, \mathrm{Zn}, \mathrm{Fe}$ and $\mathrm{Mn}$ in shoot dry matter of L. leucocephala and M. caesalpiniaefolia (Tables 7 and 8, respectively) were not affected for the inoculation with rhizobia.

Application of sewage effluent increased significantly the contents of $\mathrm{Zn}, \mathrm{Fe}$ and $\mathrm{Mn}$ in shoot dry weights of $L$. leucocephala and M. caesalpiniaefolia (Tables 7 and 8, respectively), compared to treatment with water irrigation, in both treatments with and without inoculation, probably reflects the increase of these micronutrients in the soil due to application of the effluent. The $\mathrm{Cu}$ content remained un- changed in response to application of the sewage effluent. Rattan et al.[30] also reported an increase of $\mathrm{Zn}, \mathrm{Fe}$ and $\mathrm{Mn}$ in the dry matter of maize irrigated with sewage effluent, compared with soil irrigated with well water. Al- Nakshabandi et al.[5] observed higher concentrations of $\mathrm{Cu}, \mathrm{Fe}, \mathrm{Mn}$, $\mathrm{Pb}$ and $\mathrm{Zn}$ in soil due to high concentration of these micronutrients in the treated sewage effluents. Similarly, Siebe[33] also found slight increases in $\mathrm{Cd}, \mathrm{Cu}$ and $\mathrm{Zn}$ in soils cropped with alfalfa and irrigated with treated sewage effluents for more than 80 years.

Table 7. Effect of sewage effluent and of the inoculation with Rhizobium on micronutrients accumulation in leucena (Leucaenaleucocephala)

\begin{tabular}{|c|c|c|}
\hline \multirow{2}{*}{ Irrigation } & \multicolumn{2}{|c|}{ Inoculation } \\
\cline { 2 - 3 } & With Rhizobium & Without Rhizobium $^{*}$ \\
\cline { 2 - 3 } & \multicolumn{2}{|c|}{$\mathrm{Cu}\left(\mu \mathrm{g}\right.$ plant $\left.^{-1}\right)$} \\
\hline Water & $3.81 \mathrm{Aa}$ & $3.84 \mathrm{Aa}$ \\
\hline Sewage effluent & $5.67 \mathrm{Aa}$ & $5.53 \mathrm{Aa}$ \\
\hline & \multicolumn{2}{|c|}{$\mathrm{Zn}\left(\mu \mathrm{g}\right.$ plant $\left.^{-1}\right)$} \\
\hline Water & $32.17 \mathrm{Ab}$ & $27.69 \mathrm{Ab}$ \\
\hline Sewage effluent & $69.51 \mathrm{Aa}$ & $45.43 \mathrm{Ba}$ \\
\hline & \multicolumn{2}{|c|}{$\mathrm{Fe}\left(\mu \mathrm{g}\right.$ plant $\left.^{-1}\right)$} \\
\hline Water & $110.43 \mathrm{Ab}$ & $63.52 \mathrm{Ab}$ \\
\hline Sewage effluent & $225.37 \mathrm{Aa}$ & $165.77 \mathrm{Ba}$ \\
\hline & \multicolumn{2}{|c|}{$\mathrm{Mn}\left(\mu \mathrm{g}\right.$ plant $\left.^{-1}\right)$} \\
\hline Water & $40.59 \mathrm{Ab}$ & $48.63 \mathrm{Ab}$ \\
\hline Sewage effluent & $127.80 \mathrm{Aa}$ & $100.20 \mathrm{Ba}$ \\
\hline
\end{tabular}

Values followed by different letters are significantly different at $\mathrm{P}=0.05$, using the Tukey test.Upper case letter compare data within rows and lower case letters compare data within columns.

Table 8. Effect of sewage effluent and of the inoculation with Rhizobium on micronutrients accumulation in sabiá (Mimosa caesalpiniaefolia)

\begin{tabular}{|c|c|c|}
\hline \multirow{2}{*}{ Irrigation } & \multicolumn{2}{|c|}{ Inoculation } \\
\cline { 2 - 3 } & With Rhizobium & Without Rhizobium $^{-1} \mathrm{Cu}\left(\mu\right.$ plant $\left.^{-1}\right)$ \\
\hline Water & $12.84 \mathrm{Aa}$ & $11.41 \mathrm{Aa}$ \\
\hline Sewage effluent & $12.24 \mathrm{Aa}$ & $10.97 \mathrm{Aa}$ \\
\hline & \multicolumn{2}{|c|}{$\mathrm{Zn}\left(\mu \mathrm{g} \mathrm{plant}{ }^{-1}\right)$} \\
\hline Water & $29.03 \mathrm{Ab}$ & $30.81 \mathrm{Ab}$ \\
\hline Sewage effluent & $104.02 \mathrm{Aa}$ & $86.12 \mathrm{Aa}$ \\
\hline & \multicolumn{2}{|c|}{$\mathrm{Fe}\left(\mu \mathrm{g}\right.$ plant $\left.^{-1}\right)$} \\
\hline Water & $94.52 \mathrm{Ab}$ & $90.67 \mathrm{Ab}$ \\
\hline Sewage effluent & $250.61 \mathrm{Aa}$ & $251.30 \mathrm{Aa}$ \\
\hline & \multicolumn{2}{|c|}{$\mathrm{Mn}\left(\mu \mathrm{g} \mathrm{plant} \mathrm{p}^{-1}\right)$} \\
\hline Water & $36.38 \mathrm{Ab}$ & $59.47 \mathrm{Ab}$ \\
\hline Sewage effluent & $207.58 \mathrm{Aa}$ & $169.66 \mathrm{Ba}$ \\
\hline
\end{tabular}

Values followed by different letters are significantly different at $\mathrm{P}=0.05$, using the Tukey test.Upper case letter compare data within rows and lower case letters compare data within columns.

The increase in growth parameters studied (height and shoot dry matter) reflects the supply of micronutrients from sewage effluent applied, and may be attributed to its influences in enhancing the photosynthesis process and translocation of photosynthetic products to the seed, as a result of increase enzymatic activity and other biological activities[1,25].

\section{Conclusions}

The results of this study indicate that application of sewage effluent increased the growth parameters (shoot dry matter and plant height) and nodulation of leguminous trees. 
With the exception of $\mathrm{Na}$, macronutrients contents increased in shoot dry matter of woody legumes with the application of sewage effluent. Micronutrient contents (except for $\mathrm{Cu}$ ) in the dry biomass of both legumes $L$. leucocephala and $M$. caesalpiniaefolia also increased with sewage effluent irrigation. Consequently, sewage effluent was efficient to improve plant growth and can be used as an alternative hydric resource in the cultivation of leguminous trees.

The results also show that inoculation with Rhizobium promoted significant increases in growth parameters, macroand micronutrients contents, only when associated with application of sewage effluent.

In conclusion, this study indicated that treated sewage effluent can be used both as a potential source of nutrients such as water supply for tree legumes, however, suggest a continuous monitoring of the effluent quality, in order to determine the residual effects of treated sewage effluent before using it as a fertilizer.

\section{ACTKNOWLEDGEMENTS}

The authors are grateful to the financial support of the Fundação de Apoio à Pesquisa do Estado do Rio Grande do Norte (FAPERN), the Conselho Nacional de Desenvolvimento Científico e Tecnológico (CNPq) by Research Grant, and to the logistic support of the Universidade Federal do Rio Grande do Norte (UFRN).

\section{REFERENCES}

[1] Aghtape, A.A., Ghanbari, A., Sirousmehr, A., Siahsar, B., Asgharipour, M., Abolfazl, T., 2011, Effect of irrigation with wastewater and foliar fertilizer application on some forage characteristics of foxtail millet (Setariaitalica). International Journal of Plant Physiology and Biochemistry, 3, 34-42

[2] Akponikpèa, P.B.I., Wimab, K., Yacoubab, H., Mermoudc. A., 2011, Reuse of domestic wastewater treated in macrophyte ponds to irrigate tomato and eggplant in semi-arid West-Africa: Benefits and risks. Agricultural Water Management, 98, 834-840

[3] Al-Fredan, M., 2006, Effect of treated municipal waste water and rhizobia strains on growth and nodulation of faba bean (Viciafaba L. cv. Hassawi). Pakistan Journal of Biological Sciences,9, 1960-1964

[4] Al-Jaloud, A.A., Hussain, G., Al-Saati, A.J., Karimulla, S., 1995, Effect of wastewater irrigation on mineral composition of corn and sorghum plants in a pot experiment. Journal ofPlant Nutrition, 18, 1677-1692

[5] Al-Nakshabandi, G.A., Saqqar, M.M., Shatanawi, M.R., Fayyad, M., Al-Horani, H., 1997,Some environmental problems associated with the use of treated wastewater for irrigation in Jordan. Agricultural Water Management, 34, 81-94

[6] Azevedo, L.P., Oliveira, E.L., 2005, Efeitos da aplicação de efluente de tratamento de esgoto na fertilidade do solo e produtividade de pepino sob irrigaçãosubsuperficial. Engen- haria Agrícola, 25, 253-263

[7] Bala, A., Murphy, P.J., Osunde, A.O., Giller, K.E., 2003, Nodulation of tree legumes and the ecology of their native rhizobial populations in tropical soils. Applied Soil Ecology, 22, 211-223

[8] Bezerra, L.J.D., Lima, V.L.A., Andrade, A.R.S., Alves, V.W., Azevedo, C.A.V.,Guerra, H.O.C., 2005, Analise de crescimento do algodão colorido sob os efeitos da aplicação de água residuária e biossólidos. Revista Brasileira de Engenharia Agrícola e Ambiental, 10, 333-338

[9] Chong, K., Wynne, J.C., Elkan, G.H., Schneeweis, M., 1987, Effects of soil acidity and aluminium content, growth and nitrogen fixation of peanuts and other grain legumes. Tropical Agriculture, 64, 97-104

[10] Daudin, D., Sierra, J., 2008, Spatial and temporal variation of below-ground $\mathrm{N}$ transfer from a leguminous tree to an associated grass in an agroforestry system. Agriculture Ecosystems and Environment, 126, 275-280.

[11] David, S., Raussen, T., 2003, The agronomic and economic potential of tree fallows on scoured terrace benches in the humid highlands of Southwestern Uganda.Agriculture Ecosystems and Environment, 95, 359-369

[12] EMBRAPA - Empresa Brasileira de Pesquisa Agropecuária. Manual de análises de solos, plantas e fertilizantes. Embrapa Solos., 1999, Brasília: Embrapa Comunicação para Transferência de Tecnologia, 370p

[13] EMBRAPA - Empresa Brasileira de Pesquisa Agropecuária. Sistema brasileiro de classificação de solos, 2006,SPI, Brasília, Brasil, 412 p. [20]

[14] Falkiner, R.A., Smith, C.J., 1997, Changes in soil chemistry in effluent irrigated Pinusradiata and Eucalyptus grandis.Australian Journal of Soil Research, 35, 1997, 131-147

[15] FAO., 1988, Soil Map of the World. Revised legend. World Soils Resources Report 60, Food and Agriculture Organization of the United Nations. Rome

[16] Fonseca, A.F., Melfi, A.J., Monteiro, F.A., Montes, C.R., Almeida, V.V., Herpin, U., 2007, Treated sewage effluent as a source of water and nitrogen for Tifton 85 bermudagrass. Agricultural Water Management, 87, 328-336

[17] Fonseca, A.F., Melfi, A.J., Montes, C.R., 2005, Maize growth and changes in soil fertility after irrigation with treated sewage effluent. II. Soil acidity, exchangeable cations, and sulfur, boron and heavy metals availability. Communications in Soil Science and Plant Analysis, 36, 1983-2003

[18] Gehring, C., Vlek, P.L.G., Souza, L.A.G., Denich, M., 2005, Biological nitrogen fixation in secondary regrowth and mature rainforest of central Amazonia. Agriculture Ecosystems and Environment, 111, 237-252

[19] Grattan, S.R., Grieve, C.M., Poss, J.A., Robinson, P.H., Suarez, D.L., Benes, S.E., 2004, Evaluation of salt-tolerant forages for sequential water reuse systems. I. Biomass production. Agricultural Water Management, 70, 109-120

[20] IPA - Empresa Pernambucana de Pesquisa Agropecuária. Cavalcanti, F. J. A. C. (Coord.). Recomendação de adubação para o Estado de Pernambuco $2^{\circ}$ aproximação. Recife: IPA, 1998. $198 \mathrm{p}$

[21] Jacomine, P.K.T., Silva, F.B.R., Formiga, R.A., Almeida, 
J.C., Beltrão, V. A., Pessôa, S.C.P., Ferreira, R.C., 1971, Levantamento Exploratório - Reconhecimento de Solos do Estado do Rio Grande do Norte. Recife: SUDENE-DRN, 531p. (Boletim Técnico, 21)

[22] Jube, S.L.R., Borthakur, D., 2010, Transgenic Leucaenaleucocephala expressing the Rhizobium gene pydA encoding a meta-cleavage dioxygenase shows reduced mimosine content. Plant Physiology and Biochemistry, 48, 273-278

[23] Kiziloglu, F.M., Turan, M.,, Sahin, U.,Kuslu, Y., Dursun, A., 2008, Effects of untreated and treated wastewater irrigation on some chemical properties of cauliflower (Brassica olerecea L. var. botrytis) and red cabbage (Brassica olerecea L. var. rubra) grown on calcareous soil in Turkey. Agricultural Water Management, 95, 716-724

[24] Leal, R.M.P., Firme, L.P., Montes, C.R., Melfi, A.J., Piedade, S.M.S., 2009, Soil exchangeable cations, sugarcane production and nutrient uptake after wastewater irrigation. Scientia Agricola, 66, 242-249

[25] Malavolta, E., 2006, Manual de nutrição mineral de plantas. Editora Agronômica Ceres. São Paulo, 638 pp

[26] Medeiros, S.S., Soares, A.A., Ferreira, P.A., Neves, J.C.L., Souza, J.A., 2008, Utilização de água residuária de origem doméstica na agricultura: Estudo do estado nutricional do cafeeiro. Revista Brasileira de Engenharia Agrícola e Ambiental, 12, 109-115

[27] Melo, H. N. S., Miranda, R. J. A., Moura, L.R.B.,Melo Filho, C.P., Andrade Neto, C. O., Lucas Filho, M., 2002,II-082 Hidroponia com esgoto tratado - Técnica do filme nutriente. VI Simpósio Ítalo Brasileiro de Engenharia Sanitária e Ambiental. Associação Brasileira de Engenharia Sanitária e Ambiental (ABES)

[28] Mohammad, M.J., Ayadi, M., 2004, Forage yield and nutrient uptake as influenced by secondary treated wastewater. Journal of Plant Nutrition, 27, 351-364

[29] Overman, A.R., 1981, Irrigation of corn with municipal effluent. Transactions of the American Society of Agricultural Engineers, 24, 74-80

[30] Rattan, R.K., Datta, S.P., Chhonkar, P.K., Suribabu, K., Singh, A.K., 2005, Long-term impact of irrigation with sewage ef- fluents on heavy metal content in soils, crops and groundwater - a case study.Agriculture Ecosystems and Environment, 109, 310-322

[31] Rogers, M., Smith, S. R., 2007, Ecological impact of application of wastewater biosolids to agricultural soil. Water Environment Journal, 21, 34-40

[32] Römheld, V., 1986PH changes in the rhizosphere of various crop plants in relation to the supply of plant nutrients. Potash Review, 12, 1-12. [37]

[33] Siebe, C., 1995, Heavy metal availability to plants in soils irrigated with wastewater from Mexico City. Water Science and Technology, 32, 29-34

[34] Silva, F.A.S.E., 1996, The ASSISTAT Software: statistical assistance. In: INTERNATIONAL CONFERENCE ON COMPUTERS IN AGRICULTURE, 6., Cancun, 1996. Anais. Cancun, American Society of Agricultural Engineers, p.294-298

[35] Souza, L.A.G., BezerraNeto, E., Santos, C.E.R.S., Stamford, N.P., 2007, Development and natural nodulation of legume trees in soils from Pernambuco, Brazil. PesquisaAgropecuáriaBrasileira, 42, 207-217

[36] Stamford, N.P., AraújoFilho, J.T., Silva, A.J.N., 2000, Growth and nitrogen fixation of Leucaenaleucocephala and Mimosa caesalpiniaefolia in a saline soil of the Brazilian semi-arid region as affected by sulphur, gypsum and saline water. Tropical Grasslands, 34, 1-6

[37] Stamford, N.P., Silva, A.J.N., Freitas, A.D.S., AraújoFilho, J.T., 2002, Effect of sulphur inoculated with Thiobacillus on soil salinity and growth of tropical tree legumes. Bioresource Technology, 81, 53-59

[38] Stamford, N.P., Silva, R.A., 2000, Efeito da calagem e inoculação de sabiá em solo da mata úmida e do semi-árido de Pernambuco. Pesquisa Agropecuária Brasileira, 35, 10371045

[39] Toze, S., 2006, Reuse of effluent water - benefits and risks. Agricultural Water Management, 80, 147-159 